\title{
Effective strategies in internationalization of higher education in the United States
}

Özturgut, Osman

University of the Incarnate Word, USA (ozturgut@uiwtx.edu)

Cantu, Maria P.

University of the Incarnate Word, USA (mpcantu@ student.uiwtx.edu)

Pereira, Leo J.

University of the Incarnate Word, USA (lipereir@ student.uiwtx.edu)

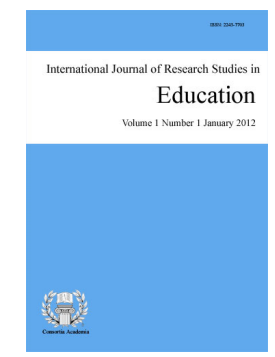

ISSN: 2243-7703 Online ISSN: 2243-7711

OPEN ACCESS

Ramón, Denise K.

University of the Incarnate Word, USA (dkramon@student.uiwtx.edu)

\section{Abstract}

This qualitative study investigated the existing outlooks of internationalization in higher education in US universities having a sizable international student population attending their campuses. The purpose of this research was to explore the common practices for internationalization of higher education in US institutions. This study utilized Zha's (2003) conceptual and organizational framework of internationalization of higher education: the activity approach, which includes curricula, studying abroad, internationalizing faculty, and recruitment of international students. Other components of the framework include: the competency approach, which includes development of knowledge and skills, the ethos approach which focuses on the infusion of intercultural and international initiatives, and the process approach which seeks internationalization by means of inclusion of international and intercultural dimensions into teaching, service, and research. A correlation was discovered between the cited literature and raw data that was analyzed. The main themes indicating current practices that higher education institutions were employing to increase internationalization were: 1) hosting international events for training and education on culture and diversity, and 2) having international dimensions within their institutional infrastructure. This study suggests that internationalization of higher education in the United States needs to continue, evolve, and expand, especially since globalization trends make it more pertinent to the understanding of various cultures. In order for higher education in the United States to be competitive and viable in the global market, there needs to be a sustained goal in internationalizing teaching, learning, and practices.

Keywords: internationalization; higher education; globalization; culture; American universities 


\section{Effective strategies in internationalization of higher education in the United States}

\section{Introduction}

Some of the most visual realities shaping the United States are changing demographics, the global economy, and information technology. The increasing attention and emphasis for internationalization of higher education, as a direct result of growing global trends in economy and global inter-dependence, create challenges for US universities. To respond to this reality, institutions are paying increasing attention to recruiting students from other countries, internationalizing the curriculum, and bridging between international education and corporate interests (Cudmore, 2005). Most of the US universities in essence embrace the concept of internationalization by incorporating this in their mission statements and publications (Miller-Idriss \& Worden, 2010; Theovald, 2004). In the $21^{\text {st }}$ century context, the need for internationalization of higher education is a response to the global economy and labor market demands with an increasing need for professionals in the field of global business. As Merriam, Caffarella, and Baumgartner (2007) recount, higher and adult education have no boundaries.

\subsection{Purpose statement}

The purpose of this study was to find out the best practices and effective strategies in internationalization of US higher education institutions. Through this study, the authors examined the current practices of internationalization of higher education in US universities, with vast presence of international students on their campuses and make recommendations to improve the understanding and the quality of internationalization efforts.

\subsection{Significance of the study}

Emphasizing the importance of internationalizing higher education, Salisbury, Umbach, Paulsen, and Pascarella (2009) argued that studying in multicultural settings increases compassion and respect for global issues, positive attitudes toward other cultures, and better intercultural communication skills and self-image. Roberts, Chou, and Ching (2010) claimed that internationalization was present in various dimensions in higher education. University policies, initiatives, and practices were being adjusted in the context of globalization. As Roberts et al. (2010) quoted Knight: "internationalization is changing the world of education and globalization is changing the world of internationalization" (p.152).

McBurnie (2000) explained that strategizing internationalization of higher education included three components: a) international composition of student body, b) foundation and development of overseas campuses, and c) the assurance of internationalizing the learning experience. For the United States, one of the major challenges in higher education in the $21^{\text {st }}$ century is to maintain a highly capable, intellectually, and culturally competent workforce in a fast changing world (Deardorff, 2004). Pandit (2009) argued that students were required to face the globalized world. Therefore, they should enhance their scholarship and innovation and be able to nurture economic bridges between communities and the world.

Further, in post-world war era, international education is considered as a means of peace and mutual understanding and became an internationally traded commodity. Therefore, as Stensaker, Frølich, Gornitzka, and Maassen (2008) stated, it is important to study the views of higher education institutions in the US regarding their internationalization efforts and how they accommodate initiatives, progresses, and policies of internationalization. 


\section{Review of Related Literature}

\subsection{Definition of Internationalization}

To create a context for this research, it is important to define internationalization. Internationalization, as described by Deardorff (2004) is a process that incorporates international perspective in learning, research, and service in the traits of higher education. Deardorff (2004) quotes the American Council of Education (ACE), in defining internationalization as:

a broad range of intellectual and experiential activities designed to help individuals understand the global environment in which they live, communicate across borders, and acquire an understanding of the cultural, social, and political systems of other nations and the interactions between nations (pp. 4-5).

Hsu (2012) argued that in current context of higher education, campuses incorporated the people of different nations and countries and dissolved the man-made barriers of communication, knowledge, and services. Hsu (2012) claimed that internationalization was a process to initiates policies to adapt various cultural knowledge and competencies and their practices in campus community.

According to Qiang (2003), internationalization is a response of a nation to the effect of globalization and it is "any systematic, sustained efforts aimed at making higher education responsive to the requirements and challenges related to the globalization of societies, economy and labor markets" (p. 250). There is a common distinction between globalization and internationalization in higher education scholarship. Globalization is seen as an over-arching social and economic process, whereas internationalization is understood as the ways in which institutions of higher education respond to globalization (Cantwell \& Maldonado, 2009).

\subsection{History of International Education in American Universities}

The topic of internationalization of American higher education has received tremendous amount of attention from researchers and scholars in the past decades (Altbach, 2004; Knight, 2004; Scott, 2000; Van Der Wende, 2001). In the late 1990s, the American Council on Education (ACE) published a series of reports on internationalization in American universities and supportive programs to bring about internationalization (ACE 1999, 2003). Almost simultaneously, leaders from 29 European countries signed a declaration that resulted in the Bologna Process, a consorted effort to improve the quality of European universities as a way to attract international students and researchers from around the world and perspective international employers for their graduates (Pandit, 2009).

There is nothing new about internationalization of American universities. Since the first US universities were created, there have been foreign language training programs (de Wit, 2002), and students and scholars have been mobile to and from US institutions ever since (Altbach, 1998). The study of international education became more focused after World War II (Hines, 2001). Language training and cultural knowledge were requirements to rebuild the countries destroyed by war. International education became an instrument of peace and mutual cooperation by which the United States could exercise its power. According to Ruther (2002), the Fulbright Act of 1946 propelled the pull of international students to the United States and the push of American students to study abroad. The prevailing idea behind these international collaborations was that world leaders educated in American universities would align with the US when their time came to represent their countries in international affairs (De Wit, 2002; Ruther 2002).

High technology innovations in the United States in the 1980's also attracted a great number of science and engineering students, mainly from China and India. These students were recruited by major corporations upon graduation and helped bring about the high tech revolution of the 1990's (Saxenian, 1990 as quoted in Pandit 
2009). In addition to technological advancements at the turn of the millennium, September 11, 2001 (9/11) brought back the philosophy of international student recruitment as an imperative to build alliances with other countries and to prevent future attacks on America (Pandit, 2009). The restructuring of higher education in the past two decades has contributed to the making of American universities into an internationally traded commodity (Altbach, 2006; Harris, 2008; Slaughter \& Roades, 2004).

Chou, Roberts, and Ching (2012) argued that pull factors had been a significant influence on students to choose study abroad and contribute to internationalize higher education campuses. Knowledge and access to information, reputation and quality of institutions, recommendation of others in personal level, financial issues fees and other expenses, presence of students of same country and option for part-time jobs, environment, geographic and time closeness, and social link - presence of family members or friends were identified as the components and ties that drew the international students.

\subsection{Conceptual Framework}

Zha Qiang (2003) stressed the need for a more explicit definition of internationalization to overarch the complete functioning of higher education and provided a conceptual and organizational framework. He identified four key approaches to internationalization:

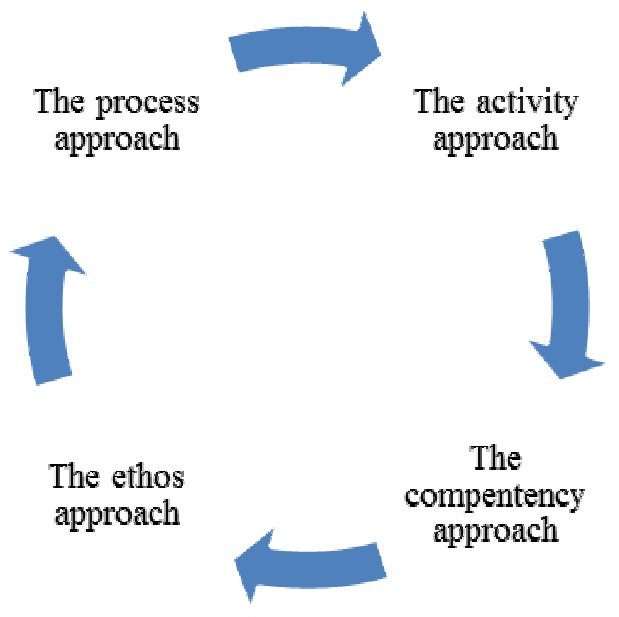

Figure 1. Conceptual and organizational framework for internationalization of higher education

\subsection{The Activity Approach}

The activity approach is a theoretical account that analyzes human practices while it continues to develop. Three underlying traits of this framework are: a) it heads toward an ideal goal that differentiates one action from another, b) it acts through artifacts (tools, language), and c) it includes societal aspects within its accomplishment (Bardram, 1997). For "The activity approach includes activities such as curriculum, student and faculty exchange, technical assistance and international students" (Qiang, 2003, p. 250). From 1970 to 1980, the activity approach became the norm and symbol of international education (Qiang, 2003). Activity approach includes higher education institutions designing curriculum to prepare faculty and students for global citizenship (Bresciani, 2008), providing study abroad opportunities for students, faculty development programs, international curricula expansion, international study and research, international faculty exchange programs, and international student recruitment.

\subsection{The Competency Approach}

The competency approach emphasizes the development of skills, knowledge attitudes, and values in students, faculty and staff (Qiang, 2003, p. 250). 
In order to better serve international students and to prepare a diverse population of American students to compete in the global market, the student affair personnel, faculty, and staff in American universities need to master their own global competencies (Hammerick 2002; Love \& Estanek, 2004; Sandeen \& Barr, 2006). Anderson (2007) identified multicultural competencies as global competencies. Sue et al. (1982, 1992), Casas et al. (1986), Pedersen (1988), and Pope and Reynolds (1997) identified awareness, knowledge, and skills as basic components of multicultural competencies.

\subsection{The Ethos Approach}

The ethos emphasizes creating a culture or climate that values and support international/intercultural perspectives and initiatives (Qiang, 2003, p. 250)

Knight, (2004) underscored the importance of pedagogical approaches to international education by providing a working definition of internationalization in higher education: "the process of integrating an international, intercultural or global dimension into the purpose, functions or delivery of postsecondary education" (p. 11). According to Knight (2004), internationalization includes "academic standards, cultural diversity, student and staff development, and income generators" (p. 20). Knight and de Wit (1995) and Hsu (2012) envisioned internationalization with the implementation of a wide range of policies, services, and activities designed to integrate intercultural and international dimensions into an institution's student services, curricula teaching, and research. Bennet (1993) addressed intercultural sensitivity, cultural tolerance, and ethnic diversity. Weiss (1988) described the existence of "transnationalism": "It implies an open market place free of institutional or locational constraints..." (pp. 168-169). He refers to institutions which cross borders and nations implementing processes without requiring authority from their own countries or states.

\subsection{The Process Approach}

The process approach stresses integration or infusion of an international intercultural dimension into teaching, research and service, through a combination of a wide range of activities, policies and procedures (Qiang, 2003, p. 250)

Stier (2004) depicted the creation of a climate that would support the American universities' specific visions of internationalization in the curricula, policies, organizations teaching, and research strategies. According to Shore and Groen, (2009) doing collaborative international work "involves building and sustaining inter and intra-institutional relationships, catalytic events which 'make things happen' and learning from each other via common and divergent institutional practices" (p. 533). Knight (2004), Van der Wende (2001), and Van Damme (2001) illustrated strategies for initiating partnerships and international collaboration, which include student and faculty exchanges; enrollment in courses at a partner university as a substitution for courses students would normally take at their home universities; and faculty conducting research and teaching in a host university which brings about changes in curricula of their home institutions. Van Damme (2001) and Knight (2004) also explored regulation, validation, comparability, and standardization of international partnerships.

\section{Methodology}

The purpose of this study was to find out the best practices for internationalization of higher education on US campuses. Qualitative research was used to gather and analyze data. One hundred sixty (160) US institutions hosting international students with the highest number of international students on their campuses in 2010 were selected for this study (Institute of International Education, 2010).

\subsection{Participants institutions}

To find out current practices and performances in internationalization, the top forty (40) institutions with the highest numbers of international students on their campuses, from each Associate's, Baccalaureate, Master's, and 
Özturgut, O., Cantu, M. P., Pereira, L. J., \& Ramón, D. K.

Doctoral institutional programs (Carnegie Classification, 2005) were surveyed. Every one of the 160 institutions were emailed with a link (SurveyMonkey ${ }^{\mathrm{TM}}$ ) asking to fill in a survey.

\subsection{Survey tool}

The survey questions were derived from Qiang's (2003) approaches for internationalization of higher education:

$>$ Please list 5 best practices your institution is currently utilizing internationalization activities such as curriculum, student/faculty exchange, technical assistance, and international students.

$>$ Please list 5 best practices your institution is currently utilizing in emphasizing the development of skills, knowledge, attitudes, and values in students, faculty, and staff so that they become more internationally knowledgeable and inter-culturally skilled.

$>$ Please list 5 best practices your institution is currently utilizing to emphasize creating a culture or climate that values and supports international/intercultural perspectives and initiatives.

Please list 5 best practices your institution is currently utilizing to stress integration or infusion of an international/intercultural dimension into teaching, research.

Survey questions were sent to university administrative personnel related to international admissions. The participants of the survey were university administrators working with the international students and international academic programs, for example, Vice President, Director, Associate, and Assistant Directors of International Programs, as well as, Director, Associate, and Assistant Directors of International Admissions. Responses were kept anonymous and confidential. Out of 160 institutions surveyed, 22 doctoral, 14 Masters, 9 Baccalaureate, and 8 Associate's institutions responded to the survey ( $\mathrm{N}=53)$.

\section{Results}

\subsection{Process of analysis}

Data collected through this study was analyzed inductively and deductively. A list of thematic codes was developed based on an initial read of the survey responses. Inductive analysis was conducted through "discovering patterns, themes, and categories in one's data" (Patton, 2002, p. 453) and deductive analysis was conducted through some of the categories developed "according to an existing framework" (p. 453), which was the review of recent related literature (priori codes). The researchers utilized preliminary research and related literature as the guidelines for the data analysis: "this early grounding and planning can be used to suggest several categories by which the data could initially be coded for subsequent analysis" (p. 209). As the researchers read and reread the data in depth, multiple themes emerged in addition to the themes that "were derived from the researcher's insider sense of issues that would occur in real life" (Marshall \& Rossman, 2011, p. 211). The codes after the initial read were shifted and modified as the researchers reread and rethought the data (Bogden \& Biklen, 1998; Marshall \& Rossman, 1989). Further engagement with the data helped generates the final themes. These themes "then became buckers or baskets into which segments of text are placed" (Marshall \& Rossman, 2006, p. 159).

\subsection{Findings and descriptions}

This particular study scrutinized the current dispositions and practices of internationalization in higher educational institutions. It sought out US universities with the highest number of international students on their campuses. One hundred sixty (160) US institutions hosting the highest number of international students on their campuses in 2010 were selected to participate in an anonymous and confidential survey based from Qiang's 
(2003) approaches for internationalization of higher education. A total of 53 universities responded to the survey. Data collected through this study was inspected inductively and deductively. Results are found in Table 1 . The majority of the survey responses came from the doctoral level with $50 \%$ of the responses versus $18 \%$ from the master's level and $16 \%$ from the baccalaureate and associate's levels. From the open-ended answers on the survey, seven themes emerged, as noted in Table 1.

One theme references to the implementation of study abroad and other similar programs, such as student or faculty exchanges. Theme two was the involvement of faculty and staff in the various mechanisms of international activities and programming that a university offers. This ranged in responses from having faculty conduct international research and staff participating in cultural learning events. Both theme one and two each compiled $13 \%$ of the incidences reported. Another theme speaks to ongoing projects, such as service learning projects and hosting international students or faculty, with four percent of the incidences reported. One campus stated that it has a program that "places native students with international students". The next theme found was adding international subjects in the curriculum and having formal course with direct teaching on culture and other topics dealing with globalization and international studies. It had $11 \%$ responses in relation to this theme. Following the fourth theme is the fifth with the implementation of international research development and participation. Nine percent of participants mentioned research in their responses. As noted in Table 1, there were no responses regarding three of these themes at the associate's level.

Table 1

Coding Information from Raw Data from Surveys Regarding Internationalization in Higher Education in the US

\begin{tabular}{|c|c|c|c|c|c|}
\hline Theme & $\begin{array}{c}\text { Total } \\
\text { Responses }\end{array}$ & $\begin{array}{l}\text { Doctoral } \\
\text { Level }\end{array}$ & $\begin{array}{l}\text { Master's } \\
\text { Level }\end{array}$ & $\begin{array}{l}\text { Baccalaureate } \\
\text { Level }\end{array}$ & $\begin{array}{l}\text { Associate's } \\
\text { Level }\end{array}$ \\
\hline $\begin{array}{l}\text { Implementation of study abroad and } \\
\text { like programs }\end{array}$ & 15 & 6 & 4 & 3 & 2 \\
\hline Faculty /staff involvement & 15 & 8 & 3 & 0 & 4 \\
\hline $\begin{array}{l}\text { Hosting international events for } \\
\text { training and education on culture and } \\
\text { diversity }\end{array}$ & 25 & 15 & 5 & 1 & 4 \\
\hline Ongoing projects & 5 & 1 & 3 & 2 & 0 \\
\hline $\begin{array}{l}\text { Addition of international subjects in } \\
\text { curriculum }\end{array}$ & 13 & 4 & 2 & 7 & 0 \\
\hline $\begin{array}{l}\text { Implementation of international } \\
\text { research }\end{array}$ & 10 & 4 & 5 & 1 & 0 \\
\hline $\begin{array}{l}\text { Having international dimensions } \\
\text { within institutional Infrastructure }\end{array}$ & 34 & 19 & 4 & 4 & 7 \\
\hline Overall Total Responses & 94 & 47 & 17 & 15 & 15 \\
\hline
\end{tabular}

The last themes on Table 1 are the top two reoccurring patterns that indicate current practices that higher education institutions are implementing in order to increase internationalization. Each theme had the majority of the responses, with $21 \%$ and $29 \%$ respectively. They are: (1) hosting international events for training and education on culture and diversity, and (2) having international dimensions within institutional infrastructure. The first practice of hosting and sponsoring single events on or in relation to higher educational campuses is correlated to responses including, but not limited to trainings, workshops, conferences, presentations, and festivals. These experiences deal with international diversity and cultural issues and awareness. The second top practice alludes to the infrastructure in place at the campuses. This deals with institutional organization including, 
Özturgut, O., Cantu, M. P., Pereira, L. J., \& Ramón, D. K.

but also unrestricted to methods such as, the creation of global profiling, diverse environments, and international positions. Also within the second mode of internationalization lies the process for recruitment and enrollment of international students. Some direct survey responses incorporated in this theme are: having web pages in alternate languages, improving global networking, having campuses and centers outside the US, and having international offices and counselors.

\section{Discussion}

Conceptual framework of this study has used four components - activity approach, competency approach, ethos approach, and process approach - to explore international dispositions. Responses of all four types of institutes - Doctoral, Master's, Baccalaureate, and Associate's - are categorized and incorporated under the components.

\subsection{Activity Approach}

The activity approach which, encourages activities such as curriculum, student and faculty exchange, technical assistance, and international students (Qiang, 2003) is prevalent in the following theme findings: implementation of study abroad and alike programs, hosting international events for training and education on culture and diversity, strategic planning for globalized curriculum, and addition of international subjects in curriculum.

Respondent institutes report:

We actively encourage participation in study abroad; Offer study abroad opportunities for US students; Expanding focus on education broad through additional study abroad programs. International enrichment seminar class (optional/first year students); We host several large scale intercultural festivals - including world fest and international week; The center for international studies hosting workshops on intercultural awareness; Hiring international faculty.

\subsection{Competency approach}

The competency approach which, focuses on development of knowledge and skills, values, and attitudes in faculty, staff and students (Qiang, 2003) is represented in the following theme findings: study abroad and exchange programs, international and intercultural seminar, training, workshops and research for faculty and students, and develop interpersonal skills.

For example, respondent institutions report:

"offer study abroad opportunities for US students", "provide faculty development grants for international activities", "the Center for Internationals Studies hosting workshops on intercultural awareness", in another level: "promoting study abroad programs", "educating faculty and staff through IDI testing and continuing education activities and workshops", for another level: "encouraging study abroad", "expanding international programs off campus", and at the Associate's Level: 'faculty-driven study abroad courses", study abroad program which includes faculty", and "cultural competency workshops on campus".

\subsection{Ethos approach}

The ethos approach which, seeks to create an organizational culture which values and encourages international/intercultural initiatives (Qiang, 2003) is found in the following themes: cultural diversity, promotion of internationality, intercultural activities, building bridge with the community, and intercultural values. Creating an environment that values diversity and culture have been very crucial. 
Similar responses were found in the respondent institutions' report:

"Hosting international events for training and education on culture and diversity; implementation of international research; having an international dimensions within institutional infrastructure; campus wide international events and celebrations; supporting international cultural organizations and clubs; creating an office of multicultural students affairs; and recruitment of international students."

\subsection{Process approach}

Finally, the process approach, which emphasizes an immersion of the Intercultural/International dimension into teaching, service and research, adopting policies and procedures (Qiang, 2003), are identified in the following themes: faculty /staff involvement, continuing projects, curriculum and teaching, having international dimensions within institutional infrastructure, and strategic plan.

Practices of respondent institutes were:

Several departments have ongoing development project worldwide; Strategic mission statement; creation of curriculum integration of study abroad; faculty that have collaborative research with international partner; Committee of internationalization; cross-cultural requirements in curriculum; Faculty taskforce and advisory council to push international agenda on the curriculum development.

The literature defining internationalization, denoting the history of its evolution and in the outlining of the conceptual framework was mirrored in all four approaches. Many participants' responses aligned with Miller-Idriss and Worden (2010) that pointed out first trends in internationalization, encouraging study abroad programs. Other similarities found between literature and responses were the mention of founding institutions, campus or programs in other countries (Callan, 2000; Deardorff, 2004; Kirtz, 2006, \& Miller-Idriss \& Worden, 2010). Even with all the likenesses between the data and literature, no participants directly mentioned the use of online education and technology as cited by Deardorff, (2004). Overall, qualitative data collected held validity.

Having understanding issues of internationalization, obtained data from participant-institutes, evidence from literature, and necessary changes needed to in enhance internationalization of higher education, table 2, presents a snapshot of the internationalization in higher education institutions in the US.

\section{Conclusion and Recommendations}

The purpose of this study was to find out the best practices in internationalization of US universities. Institutions and departments play a critical role in the formation of an academic environment that encourages the faculty, staff, and students to become agents of the internationalization process (Ray \& Solem, 2009) while benefiting from this exchange. Internationalization of higher education in the United States needs to stay on course and continue to evolve and be encouraged to expand. As globalization continues, understanding of cultures and interactions of Americans with others from international diverse backgrounds is necessary so that problem solving, communication, and shared knowledge can be meshed into all interacting societies. In order for higher education in the United States to be competitive in the global market, there needs to be a continued push for higher learning that incorporates practices that have international components as well as practices that are geared towards increasing the cultural competency of the stakeholders involved in this endeavor.

There is always the question whether the internal or external validity of the study may have been compromised as with all research studies. Results for this qualitative study may not necessarily be generalizable since all circumstances for this research were unique. However, the purpose was not to generalize the findings but provide a roadmap for US higher education institutions in helping with the internationalization efforts and further contribute to the discussion of internationalization. The suggested variants to repeat the study include: 
Özturgut, O., Cantu, M. P., Pereira, L. J., \& Ramón, D. K.

asking more universities to participate and to ensure that the universities come from all of the major regions of the United States. Another suggestion for a similar research is to ask for more associate's and baccalaureate level participation.

Table 2

At a glance - from understanding of internationalization to new ideas

\begin{tabular}{|c|c|c|c|}
\hline $\begin{array}{l}\text { Understanding of } \\
\text { internationalization }\end{array}$ & $\begin{array}{l}\text { Current common } \\
\text { practices }\end{array}$ & Areas to improve & $\begin{array}{l}\text { New ideas for } \\
\text { consideration }\end{array}$ \\
\hline $\begin{array}{l}\text { Curriculum; } \\
\text { student and faculty } \\
\text { exchange; international } \\
\text { students }\end{array}$ & $\begin{array}{l}\text { Study abroad; students } \\
\text { and faculty exchange; } \\
\text { recruiting international } \\
\text { students and faculty }\end{array}$ & $\begin{array}{l}\text { Eurocentric curriculum; } \\
\text { North America based } \\
\text { curriculum }\end{array}$ & $\begin{array}{l}\text { Creation of multicultural } \\
\text { and international } \\
\text { curriculum }\end{array}$ \\
\hline $\begin{array}{l}\text { Development of skill, } \\
\text { knowledge and values of } \\
\text { students, faculty and staff }\end{array}$ & $\begin{array}{l}\text { Faculty/staff participation } \\
\text { in international research } \\
\text { and conferences; } \\
\text { diversity training }\end{array}$ & $\begin{array}{l}\text { Limited and book based } \\
\text { knowledge of other } \\
\text { cultures } \\
\text { Know about other }\end{array}$ & $\begin{array}{l}\text { Use textbooks that } \\
\text { represent different } \\
\text { cultures; collect and } \\
\text { exhibit artifacts of other } \\
\text { cultures }\end{array}$ \\
\hline $\begin{array}{l}\text { Creating a culture of } \\
\text { international and } \\
\text { intercultural perspectives } \\
\text { and initiatives }\end{array}$ & $\begin{array}{l}\text { Hosting international } \\
\text { week, training and } \\
\text { education on culture and } \\
\text { diversity }\end{array}$ & $\begin{array}{l}\text { cultures but do not } \\
\text { understand them } \\
\text { Only few events based } \\
\text { environment }\end{array}$ & $\begin{array}{l}\text { Reciprocal experience of } \\
\text { living with native } \\
\text { families; creating } \\
\text { experiential events }\end{array}$ \\
\hline $\begin{array}{l}\text { Integration of } \\
\text { international and } \\
\text { intercultural dimension in } \\
\text { teaching, research, } \\
\text { service and policies }\end{array}$ & $\begin{array}{l}\text { Conducting international } \\
\text { research } \\
\text { Strategic plan, committee } \\
\text { on internationalization }\end{array}$ & $\begin{array}{l}\text { Quantitative focused; } \\
\text { finance based motivation }\end{array}$ & $\begin{array}{l}\text { Internationalization be } \\
\text { incorporated in mission } \\
\text { statement, and adopting } \\
\text { continuity policies and } \\
\text { procedures }\end{array}$ \\
\hline
\end{tabular}

Implications of findings to the presented theory and practice are to have US higher educational institutions to continue to promote internationalization infrastructure, event programming, and providing professional development opportunities for faculty, staff, and students to increase their competencies in cross-cultural communication. We further recommend increasing the formation of coalitions between different countries and American universities to promote American students' study abroad programs, faculty exchange and coordination of programs to promote recruitment and retention of international students. Similar research needs to persist with the intention to advance the understanding and the quality of internationalization efforts.

\section{References}

Andrade, A. D. (2009). Interpretive research aiming at theory building: Adopting and adapting the case study design. The Qualitative Report, 14(1), 42-60.

Bardram, J. E. (1997). Plans as situated action: An activity theory approach to workflow systems. Proceedings of the Fifth European Conference on Computer Supported Cooperative Work, 17-32. http://dx.doi.org/10.1007/978-94-015-7372-6_2

Callan, H. (2000). The international vision in practice: A decade of evolution. Higher Education in Europe, 25(1), 15-23. http://dx.doi.org/10.1080/03797720050002161

Chou, C. P., Roberts, A., Ching, G. S. (2012). A study on the international students' perception and norms in Taiwan. International Journal of Research Studies in Education, 1(2), 71-84. http://dx.doi.org/10.5861/ijrse.2012.v1i2.76

Cudmore, G. (2005). Globalization, internationalization, and the recruitment of international students in higher education, and in the Ontario colleges of applied arts and technology. Canadian Journal of Higher Education, 35(1), 37-60.

Deardorff, D. K. (2006). Identification and assessment of intercultural competence as a student outcome of internationalization. Journal of studies in international education, 10(3), 241-266. 
Effective strategies in internationalization of higher education in the United States

http://dx.doi.org/10.1177/1028315306287002

Enders, J. (2004). Higher education, internationalization, and the nation-state: Recent developments and challenges to governance theory. Higher Education, 47(3), 361-382.

http://dx.doi.org/10.1023/B:HIGH.0000016461.98676.30

Hsu, Tsu-Chia (2012). Enhancing college students' global awareness through campus Toastmasters clubs. International Journal of Research Studies in Education, 1(1), 21-34. http://dx.doi.org/10.5861/ijrse.2012.v1i1.1

Horta, H. (2009). Global and national prominent universities: Internationalization, competitiveness and the role of the state. Higher Education, 58(3), 387-405. http://dx.doi.org/10.1007/s10734-009-9201-5

Institute of International Education. (2011). Open door reports. Washington, DC: Author.

Jiang, X. (2008). Towards the internationalization of higher education from a critical perspective. Journal of further \& Higher Education, 32(4), 347-358. http://dx.doi.org/10.1080/03098770802395561

Jiang, X. (2010). A probe into the internationalization of higher education in the NZ context. Educational Philosophy \& Theory, 42(8), 881-897. http://dx.doi.org/10.1111/j.1469-5812.2009.00547.x

Knight, J. (2004). Internationalization remodeled: Definition, approaches, and rationales. Journal of Studies in International Education, 8(1), 5. http://dx.doi.org/10.1177/1028315303260832

Kritz, M. M. (2006). Globalization and internationalization of tertiary education. Symposium on International Migration and Development, Turin, Italy, 28-30.

McBurnie, G. (2000). Pursuing internationalization as a means to advance the academic mission of the university: An Australian case study. Higher Education in Europe, 25(1), 63-73. http://dx.doi.org/10.1080/03797720050002215

Merriam, S. B. (2002). Introduction to qualitative research. Qualitative Research in Practice: Examples for Discussion and Analysis, 3-17.

Merriam, S. B., Caffarella, R. S. \& Baumgartner, L. M. (2007). Learning in adulthood: A comprehensive guide $\left(3^{r d} e d\right.$.). San Francisco, CA: Jossey-Bass.

Miller-Idriss, C., \& Worden, E. A. (2010). Internationalization in US higher education: Studying the Middle-East in the American university. Globalization, Societies and Education, 8(3), 393-409. http://dx.doi.org/10.1080/14767724.2010.505102

Pandit, K. (2009). Leading internationalization. Annals of the Association of American Geographers, 99(4), 645-656. http://dx.doi.org/10.1080/00045600903120552

Qiang, Z. (2003). Internationalization of higher education: Towards a conceptual framework. Policy Futures in Education, 1(2), 248-270. http://dx.doi.org/10.2304/pfie.2003.1.2.5

Roberts, A., Chou, P., \& Ching, G. (2010). Contemporary trends in East Asian higher education: Dispositions of international students in a Taiwan university. Higher Education, 59(2), 149-166. http://dx.doi.org/10.1007/s10734-009-9239-4

Salisbury, M., Umbach, P., Paulsen, M., \& Pascarella, E. (2009). Going global: Understanding the choice process of the intent to study abroad. Research in Higher Education, 50(2), 119-143. http://dx.doi.org/10.1007/s11162-008-9111-x

Stensaker, B., Frølich, N., Gornitzka, A., \& Maassen, P. (2008). Internationalization of higher education: The gap between national policy-making and institutional needs. Globalization, Societies \& Education, 6(1), 1-11. http://dx.doi.org/10.1080/14767720701855550

Theobald, R. B. (2008). Internationalization: Institutions, people and programmes in Colorado. Journal of Geography in Higher Education, 32(2), 205-216. http://dx.doi.org/10.1080/03098260701731199 
Özturgut, O., Cantu, M. P., Pereira, L. J., \& Ramón, D. K. 